\title{
NAGY ÁDÁM
}

\section{„Az emlékezet forrásai”}

\section{Historiográfiai áttekintés a kollektív emlékezet, emlékezetpolitika, public history jelentőségéről, mint az emlékezetet befolyásoló, alakító és irányát meghatározó tényezőkről ${ }^{\star}$}

\begin{abstract}
Bevezetés
Tanulmányomban kísérletet teszek a kollektív emlékezet, az emlékezetpolitika (vagy történelempolitika) és a public history bemutatására, rövid historiográfiai áttekintésére. A téma a dualizmus kori parlamenti képviselők kollektív emlékezetével kapcsolatos kutatásom miatt megkerülhetetlen. Ennek oka, ahogy azt a későbbiekben bemutatom, hogy leginkább a kollektív emlékezet sajátosságai, sokfélesége, az emlékezetpolitika és a public history, mint egyre népszerűbb jelenség az, aminek összessége a legnagyobb befolyással bír az emlékezetre. Ez a hármas jelöli ki a legtöbb esetben az emlékezet tárgyát, ráirányítva az emberek érdeklődését bizonyos témákra, személyekre. A tárgy mellett a források kialakulására is nagy hatással van, hiszen a rítusok kialakítása, emlékművek állítása mind a különböző csoportok tevékenységéhez, illetve az emlékezetpolitikához kapcsolhatók, legyen szó nemzeti, vagy lokális viszonylatról. Tanulmányom során ezért megvizsgálom a kollektív emlékezet definícióját, jellegét és jelentőségét. Ezt követően bemutatom az emlékezetpolitika, majd a public history sajátosságait. Törekedtem arra, hogy állításaimat példákkal is alátámasszam.
\end{abstract}

\footnotetext{
* A tanulmány az EFOP-3.6.1-16-2016-00001 „Kutatási kapacitások és szolgáltatások komplex fejlesztése az Eszterházy Károly Egyetemen" projekt keretein belül jött létre.
} 


\section{Kollektív emlékezet}

A fogalmak közül elsőként a kollektív emlékezet kérdését szeretném körbejárni, mivel ez az alap, amire minden emlékezet építkezik. A fogalmat Maurice Hallbwachs francia filozófus és szociológus alkotta meg. Ezt a gondolatot végül Jan Assmann és felesége, Aleida Assmann tette igazán ismertté, megalapozva az emlékezetkutatás módszertanát.

A kollektív emlékezet fogalma abból indul ki, hogy az emlékezettel ugyan az egyén rendelkezik, de maga az emlékezőképesség valójában társadalmi produktum. A közösségek ugyanis bár nem rendelkeznek klasszikus értelemben vett emlékezettel, de a szocializáció révén meghatározzák tagjaik emlékezetét. Ennek a színtere a kommunikáció. Amennyiben valamilyen oknál fogva ez megszakad, életbe lép a felejtés, és az emlék elenyészik. Vagyis, a kollektív emlékezet csoportfüggő, mert bár az érzékelés egyéni, az emlékezet nem lehet az. Az egyén elfogadja és azonosul annak a csoportnak a nézeteivel, melyhez csatlakozott. ${ }^{1}$

Fontos ugyanakkor hangsúlyozni, hogy az emlékek hordozója csak részben az emberi elme, e mellett legalább olyan fontos a közeg, a társas helyzet és a kulturális szimbólumok. Ezek segítségével önthetö az emlékezet fogalmakba. Vagyis a múlt csak külső segédlettel megfogalmazható, így válik kulturális produktummá. Ez által az emlékezet kettős természetű. Egyrészt függ az idegrendszer működésétől, másfelől viszont társadalmi konstrukció. ${ }^{2}$ Vagyis ezeknek a csoportok által képviselt eszméknek fontos, hogy egy konkrét alakot öltsön. Ez lehet például egy személy, vagy kép. Erre azért van szükség, hogy kézzelfoghatóbb legyen, jobban beolvadjon az emlékezetbe. A megfogható alak mellett megfigyelhető egyfajta térbeli és időbeli kötöttség is. Ezen keresztül lesz szemlélhető a kollektíven megélt idő. Ilyenek lehetnek például a híres események, dátumok vagy ünnepnapok. ${ }^{3}$

Szintén a tér fontosságát hangsúlyozza Peter Burke, amikor azt mondja, hogy az emlékezet kialakításában a képek, illetve a cselekvések, rituálék és a kollektív reprezentációk azok, amelyek biztosítják a múlt átélését. Ezek mellett hangsúlyozza a tér fontosságát, amiben az ember el tudja helyezni magát. Itt érdemes megemlíteni, hogy a gyökerektől való elszakadás létrehoz egy szimbolikus rekonstrukciót, ami biztosítja az emlékezetben való fennmaradását. Ha egy csoport elszakad a gyökereitől, előbb-utóbb szükségét érzi annak megválaszolására, hogy honnan származik. Ide vezethető vissza Burke szerint az a 19. századi jelenség, amit Hobsbawm a hagyományok kitalálása korának nevez. ${ }^{4}$

Hobsbawm kitalált hagyományok alatt olyan gyakorlatokat ért, melyek a társadalom által elfogadott szabályok, valamint ezek rituáléja. Jelentőségük abban áll, hogy

\footnotetext{
Assmann 2018: 36-38.

Keszei 2010: 8.

Assmann 2018: 38-41.

Burke 2001: 8-14.
} 
rendszeres ismétlések által rögzít bizonyos viselkedési normákat, ezeket pedig a múlthoz kapcsolja. Valójában megpróbál minél inkább kapcsolódni a múlttal, általában egy konkrét időponthoz való kapcsolódással, vagy külsőségekben. De amennyiben ez megtörténik, kontinuitását tekintve nagymértékben mesterkéltté válik. Vagyis új helyzetet teremtenek a régire hivatkozva, vagy létrehozzák a múltat ismételve azt. Ebben áll a hobsbawmi kitalált hagyományok különlegessége. ${ }^{5}$

Ehhez kapcsolódva érdemes megjegyezni Jan Assmann azon kijelentését, mely szerint a konkrét alakokra való emlékezés során az emlékező közösség nem a múltat tartja fent. Csakis a múltnak egy, a közösség által a jelenben, saját keretei között értelmezett rekonstrukcióját. ${ }^{6}$ A múlt újra-alkotása mellett az emlékezetnek reprezentációs feladata is van. Azzal, hogy a múltat bemutatja a jövő nemzedékének, hozzájárul a jövő irányába mutató haladáshoz. Így az emlékezés egyben a tudásátadást is elősegíti. Ezt a folyamatot az írásbeliség gyorsította meg, hiszen a múlt tárolásának legfontosabb eszköze lett. ${ }^{7}$

A múlt reprezentálása során kiemelten fontos, hogy a kollektív emlékezet ezt úgy tegye meg, hogy egyaránt bemutatja a közös múltat és az egyéni sorsokat is. Ezáltal lesz képes mindenki megtalálni a maga helyét és azonosulni vele. A kettő kapcsolata határozza meg, hogy mi az, amire emlékezni kell, és mit kell elfeledni. Ennek elősegítéséért, ahogy azt már fentebb is említettem, a kollektív emlékezet a múltban keres vonatkozási pontokat, ami általában egy konkrét esemény, vagy dátum. Aleida Assmann írásában kiemeli, hogy egy egészségesen müködő demokráciában ezek a megemlékezések nem kötelező érvényűek, inkább egyfajta lehetőségek, melyek az egyén identitásától függnek. Itt az emlékezeti konstrukció létrehozója igen sokféle. Lehet az a média, a különböző pártok, de akár a polgárok is. A totalitárius rendszerekben a kép nem ennyire változatos. Itt a létrehozó minden esetben a párt. A megemlékezések pedig kötelező érvénnyel bírnak. Aleida Assmann ezeket a konstrukciókat úgy értelmezi, mint a jövő felé mutató iránytűket. Ezek alapján behatárol kategóriákat, figyelembe véve, hogy azt milyen formában teszik. Ammennyiben ezt elfogadjuk, az emlékezés lehet produktív, agresszív, erőszakra buzdító, vagy civilizáló hatású is. ${ }^{8}$

Halbwachs kollektív emlékezetének fogalmát Jan Assmann azzal bővítette ki, hogy a kollektív emlékezeten belül meghatározta a kommunikatív és a kulturális emlékezet fogalmát. A kommunikatív emlékezeten Assmann olyan emlékeket ért, melyeken az egyén a kortársakkal osztozik. Ilyen például a nemzedéki emlékezet. Amennyiben ennek hordozói kihalnak, a következő nemzedék veszi át a helyüket a nekik átadott tudás hordozójaként. Azonban ez az eleven emlékezés az idő múlásával elenyészik. Assmann az oral history alapján úgy véli, a kommunikatív emlékezet nagyjából három nemzedéken keresztül tartható fenn, ezt követően átveszi a helyét a hagyomány, vagyis beolvad a kulturális emlékezetbe. ${ }^{9}$

\footnotetext{
Hobsbawn 1983: 1-2.

Assmann 2018: 38-41.

Keszei 2010: 8.

8 Assmann 2016: 32-39.

9 Assmann 2018: 5-53.
} 
A kommunikatívval szemben a kulturális emlékezet a múlt egy szilárd pontjára irányul és szimbolikus alakzatokká módosul, ezek által kapcsolódik a jelenhez. A kulturális emlékezet egyik sajátossága, hogy magától nem terjed, gondos irányításra szorul és gyakran hajlik a textualitásra is. Éppen ez okból Assmann a költők, írók szerepét emeli ki, mint a kulturális emlékezet fö gondnokait. A költői megformáltság gondoskodik az identitásbiztosító tudás maradandó formába öntéséről, de ahhoz, hogy sikeres legyen, kollektív részvételre is szükség van. Ezek lesznek lényegében a megemlékezések és a különböző rítusok, melyek a megőrzést és az átadást biztosítják a következő nemzedékek számára. Ez a kulturális emlékezet alapvetően az írásbeliségre hajlik, de nem minden esetben. Megnyilvánulhat ugyanis hagyományokban és külsőségekben is. Ez lehet például térbeli kötődés (emlékezés tájai). Ennél az emlékezés kultúrája nem emlékművekbe helyez jeleket, hanem a tér egészére, például egy konkrét tájba. Ha a hagyományokat tekintjük, akkor pedig érdemes kiemelni az ereklyekultuszt és a halottakról való megemlékezést, mint a legitimáció fontos eszközét. ${ }^{10} \mathrm{~A}$ kollektív emlékezet hordozója szinte bármi lehet, az emlékezőtől függően. A tájakon és tárgyakon keresztül a zenemüvekig, narratívákig. A lényeg, hogy az emlékező közösség meg tudja tölteni emlékeivel. Az emlékeken keresztül az egyén egy új világot teremt, melyben hozzá hasonlókkal osztozik, elkülönítve magát más csoportoktól. Ez az egészen kis közösségektől az elképzelt közösségekig terjedhet. ${ }^{11}$ Az elképzelt közösség fogalmát Benedict Anderson határozta meg, és azt érti alatta, hogy egy nemzeten, közösségen belül a tagok nem ismerik egymást, nem is hallottak egymásról, de mégis elfogadják ugyanazokat a normákat egy közösséget alkotva, de ez a kapcsolat nem látható, csupán elképzelni lehet. ${ }^{12}$

Ehhez kapcsolható az emlékezet helyeinek fogalma, mely Pierre Nora francia történésztől ered. Azt mondja, a múlt tovatünt, nem élhető át újra, mivel a történelem felszámolta az emlékezetet. Nora az emlékezetet az örök jelenként értelmezi, még a történelem csupán a múlt egy tökéletlen rekonstrukciójaként jelenik meg. Éppen ezért a történelem csak idő és dolgok közti viszonyrendszer, még az emlékezet a megragadható dolgokban rejlik, mint a gesztusok, tárgyak, képek. Az emlékezethely az egyetlen, ahol az emlékezet megtartható. Az emlékezet megtartásának eszközeivé évforduló, ünnep és az archívum váltak. ${ }^{13} \mathrm{~A}$ történész feladata ezért az archiválás, dokumentálás lesz, mivel nem tudhatjuk, mire kell majd a későbbiekben emlékezni. ${ }^{14} \mathrm{Az}$ emlékezeti hely mindig anyagi, funkcionális és szimbolikus. Létezéséhez az emlékezet szándéka szükségeltetik, ha ez nincs meg, akkor csak a történelem helye. A történelem és emlékezet keveredik, mivel a történelem azt jegyzi meg, amit az emlékezet diktál. A nemzeti történelem is az emlékhelyekben ölt testet. Funkcionális, mert átadja és fenntartja az átadhatatlan tapasztalatot (lexikonok). Szimbolikus, mivel megkülönböztetjük a győztesek és vesztesek emlékezetét. ${ }^{15}$

\footnotetext{
${ }_{10}$ Assmann 2018: 60-65.

${ }^{11}$ Keszei 2010: 18.

12 Anderson 1996: 7-8.

13 Nora 2010: 13-19.

${ }_{14}$ Uo. 20-24.

15 Nora 2010: 27-32.
} 


\section{Emlékezetpolitika}

A kollektív emlékezet sajátosságainak bemutatása után érdemes kitérni az emlékezetpolitika kérdésére. Itt fontos ismertetni, még ha csak nagyvonalakban is, azt a történészi diskurzust, mely arra irányul, hogy ki a történelem átadásának a birtokosa, a kollektív emlékezet vagy a történész. Peter Burke meghatározása szerint nem a történész határozza meg a múlt kulcseseményeit. Mivel az emlékezetet magát társadalmi csoportok konstruálják, ők azok, akik megmutatják a történész számára, hogy mi az, ami emlékezésre méltó. ${ }^{16}$ Gyáni Gábor úgy foglal állást a kérdésben, hogy már kezdetben leszögezi: A 20. századi totalitárius rezsimek azzal, hogy a politika alá rendelték a történetírást, megrontották azt. A történelem elvesztette szavahihetöségét. Gyáni ezzel párhuzamosan a tudományos történelem és a kollektív, orális történelem harcát is megemlíti. A tudományos történelem szerinte vesztett azzal a presztízséből, hogy gyakran tévedett a kollektívával szemben. Az iskolarendszer némiképp javított a helyzeten, de a totalitárius berendezkedés alatt újabb visszaesés következett be. ${ }^{17}$ Gyáni Gáborhoz hasonló következtetésre jutott Holger Fischer is, aki szerint totalitárius rendszereknél a politika és a történelem elválaszthatatlan egységet alkot. Ennek a következménye, hogy a posztkommunista társadalmak esetében az emlékezet túlpolitizált, ami kiélezi a társadalom és a tudomány viszonyát, hiszen az értelmezések a politika miatt igen eltérők lehetnek. ${ }^{18}$ Ugyanakkor arra a kérdésre, hogy ki is írja a történelmet, az általános válasz: a győztesek.

Ezen az elméleten csavar egyet Peter Burke azzal, hogy azt írja „a történelmet a gyöztesek felejtik el". Mindig a vesztes az, aki nem tudja feldolgozni a történelmet, ezért emlékezésre ítéltetett, hogy tovább-léphessen. Úgy gondolom, Burke felvetése a magyar történelmet nézve hatványozottan igazzá válik. ${ }^{19} \mathrm{~A}$ felejtést Gyáni Gábor is hangsúlyozza, mint olyan tényezőt, ami közrejátszik a nemzet önképének alakulásában. Általában a politikai akarat irányítja (felülről kényszerített). Lényege a társadalmat megosztó események elfelejtése. ${ }^{20}$

Ez a jelenség elsősorban a traumatikus emlékezet vizsgálatánál igen szembetűnő. A traumák képesek arra, hogy szétfeszítsék az emlékezetet, réseket üthetnek a generációk közti kommunikációban. Ezek a traumák csupán emlékezéssel oldhatók fel, amennyiben ez nem történik meg, a társadalmon belül egyre nagyobb késztetés mutatkozik a pótlásukra. A traumáról való hallgatás megtörése csupán a hallgatás okára való visszatéréssel, azzal való szembenézéssel lehetséges. ${ }^{21} \mathrm{~A}$ traumatikus emlékezet kérdését, és az ezzel összekötött emlékezetben jelen lévő rossz közérzetet Aleida Assmann német

\footnotetext{
16 Burke 2001: 3-5.

17 Gyáni 2012: 357-358.

18 Fischer 2012: 389-392.

19 Burke 2001: 13.

20 Gyáni 2017: 22.

${ }^{21}$ Assmann 2016: 63.
} 
példákon keresztül mutatta be. Itt rámutatott arra, hogy a II. világháborút követően a németség nem elfojtotta magában a gonosz múltat, hanem tudatosan hallgatott róla, egyfajta nyugvó állapotban tartotta. Ez egy kollektív hallgatólagos egyezség volt, melynek tagjait az andersoni elképzelt közösség fogalmával tudjuk értelmezni. ${ }^{22}$ Ezek a kollektív emlékezetek globális szinten is kapcsolódhatnak, számtalan, akár egymástól gyökeresen eltérő narratívákat hozva létre. Azt azonban, hogy mire kell emlékezni és mi az, amit el kell felejteni, Aleida Assmann szerint alapvetően már a politikai viszonyok határozzák meg. Így sokszor a tettes-áldozat emlékezetek szük perspektívája jön létre. Ebből elsősorban a pluralizáció az, ami a kiutat jelenti. Ilyen lehet például az europaizálódás, a migráció vagy a globalizálódás, melyek során új kapcsolati szálak keletkeznek bővítve, színesítve az addigi narratívákat. ${ }^{23}$

$\mathrm{Az}$ emlékeztpolitika és történelempolitika nehezen elválasztható, és egymással szorosan összefüggő fogalmak. A történelempolitika igen nehezen definiálható. Fischer úgy értelmezi, mint olyan, a múltra hivatkozó politikai elemet, aminek célja a legitimáció, annak kisajátítása, valamint az ellenfél ebből való kizárása. Vagyis célja a legitimáció megszerzése és kizárólagos felhasználása. ${ }^{24}$ Wolfrum meghatározása ehhez igen hasonló. Olyan térként értelmezi, ahol az egymással versenyben lévő elitek megkísérlik a múltat feltölteni saját értékeikkel, hogy azt saját politikai céljaik elérésére használhassák fel. ${ }^{25}$ Gyáni Gábor szinte összemossa a történelempolitikát és emlékezetpolitikát. Azt írja, a jelent megelőző korok történelme közvetlen hasznot ér a jelennek. Mivel a múlt mindig aktualizálható. Gyáni esetében történelempolitikáról akkor beszélhetünk, amikor az állam identitáspolitikája beférkőzik a történetírói gondolkodásba is. Az emlékezetpolitikának mindig megvan az igénye arra, hogy formálja a közösség önképét. Ezért törekszik a történelem mint tantárgy a tudományos élet formálására is. Ugyanakkor nemcsak az államnak, a civil társadalomnak is megvan az erre hajló igénye. A kollektív emlékezet, mint olyan, igyekszik átvenni a hatalmat a történelem felett. Ebből a gondolatból ered Gyáni nézete, mely szembe-helyezi a kollektív emlékezetet a tudományos történelemmel. Ugyanakkor az államnak is megvan a lehetősége a tudományos történelem befolyásolására, sakkban tartására. Demokráciánál ez lényegében a kedvezményezettség, vagy a támogatások megvonása. Diktatúrák esetében azonban szélsőséges megoldások is elképzelhetők, mint például a számüzetés, vagy börtön. ${ }^{26}$

Gyáni ezt az ellentmondásosságot úgy oldja fel, hogyleszögezi: a történelemtudomány meghatározóként hat a nemzeti gondolkodásra, a kollektív emlékezet jellegéből adódóan nem lehet ennek alapja, mivel igen sokféle. Ugyanakkor a történész nem lehet egyedüli alap. A kultúrában mindenki emlékezet, de a történész feladata, hogy ne csak magyarázza, de értse is a múltat az által, hogy - rekonstruálva a kollektív

${ }^{22}$ Uo. 65.

23 Assmann 2016: 70-71.

${ }^{24}$ Fischer 2012: 394-395.

25 Uo. 395.

${ }^{26}$ Gyáni 2016: 20-23. 
gondolkodást - rámutat azok történelemformáló szerepére. ${ }^{27}$ Peter Burke a történészt mint az anomáliák őrzőjét határozza meg. Vagyis a feladata, hogy az embereket arra emlékeztesse, amit el akarnak feledni. Erre a legfontosabb eszköze maga az írás, ugyanis ezekben a forrásokban maradhatnak fenn azok az információk, melyek mintegy leleplezik az emlékezetet. Feltárják az emberek számára kínos és kényelmetlen múltat. ${ }^{28}$

A történelempolitika formáit Holger Fischer határozta meg. Ezek a történelemtagadás, manipuláció, mitizálás, felvilágosítás. Egyet kell értsek Fischerrel ennek kapcsán abban, hogy a megértés érdekében minél több szempontot egyszerre érdemes figyelembe venni. ${ }^{29}$ A történelempolitika célja tehát végső soron lehet hagyományteremtés, legitimáció, de akár delegitimáció is. Utóbbi általában azoknál a demokratikus országoknál jelentkezik, ahol megpróbálják elfelejteni a diktatórikus múltat. Így lényegében a történelempolitika a múlt értelmezésének hegemóniájáért folytatott harcként is értelmezhető. Az eszközei igen széleskörüek. Különösen igaz ez napjainkban, ugyanis hozzáférése van a különböző médiumokhoz, melyek által igen nagy felületen terjesztheti saját múltértelmezését. Ezek alapján tehát csatlakozva Fischer értelmezéséhez, a történelempolitika egy tér, mely a múltat kapcsolja a jelenhez, meghatározva azt, hogy a jelenben a múlt miképp értelmezhető. ${ }^{30}$ Gyáni Gábor a múlt jelenben való felhasználása kapcsán alkalmazza a „használható múlt” fogalmát. Ezt arra érti, hogy az emlékezetpolitika célja, hogy kiválassza a múlt azon eseményeit, mely a tömegdemokráciában folytatott hatalmi harc során leginkább célba tud érni a tömegek megnyerése érdekében. ${ }^{31}$

Ehhez kapcsolható Keszei kérdésfelvetése: Kivel lehet leginkább azonosulni? Erre azt a választ adja, hogy azokkal az ősökkel tud a társadalom azonosulni, akik jók, példamutatók. A nemzeti múlt a jelen céljait szolgálja: Mozgósít, megerősít, meggyőz. Bizonyos történelmi eseményekre való emlékezések erős érzelmeket válthatnak ki, függetlenül attól, hogy az emlékező személyesen is átélte-e, avagy sem. Demokráciákban és diktatúrákban a kommemoráció másként müködik. A létrehozott kánon az ünnepnapokon jelenik meg. Az, hogy mi kerül a kánonba, és válik a kulturális emlékezet részévé, az ideológiától függ. Ha sikeres, megerősíti a mi-tudatot, legalább a megemlékezés idejére. ${ }^{32}$ Ezzel kapcsolatban az ünnepnapok sikerességét, minőségét Aleida Assmann három tényezőhöz köti. Az első az érzelmisülés. Ez alatt azt érti, hogy lennie kell valamilyen érintettségnek az emberek és az ünnep között. A második a megrendezettség. Ennél fontos kérdés, hogy milyen a rituális megemlékezés jellege, mivel az könnyen kiüresedhet és szinte már jelentéstelen ismétlésekké silányulhat. A harmadik tényező az intézményesülés, mivel intézményi keretek hagyományozzák át a jövő számára a rituálékat. ${ }^{33}$

\footnotetext{
27 Uo. 28-34.

28 Burke 2001: 18.

29 Fischer 2012: 395.

30 Uo. 396-408.

31 Gyáni 2016: 32.

32 Keszei 2010: 13-14.

33 Assmann 2016: 106.
} 
A megemlékezéseknek igen tág spektruma létezik. A különböző állami ünnepségek, civil kezdeményezésű kommemorációk, tudományos kutatások, vagy akár a filmek, egy emlékezetpiramist építenek fel. Ennek a csúcsát Aleida Assmann írása alapján a szimbólumpolitikai rítusok foglalják el. Ennek elsődleges célja, ahogy azt korábban is említettem, a legitimáció elnyerése. Ennek érdekében törekednie kell a sokszínűségre, mivel így több közösséget megszólíthat. Amennyiben ez nem teljesül, az emlékezés érdektelenségbe süllyedhet. Ez a politikai rítus kiüresedését eredményezi. Egy nemzeti ünnepség kiüresedése azonban az egész társadalmat, mint egy elképzelt közösséget érinti. $^{34}$

A politikai rítusok azért is különösen fontosak, mert más módon nem megvalósítható reprezentatív funkciót töltenek be. Aleida Assmann meghatározása szerint ezek a funkciók a szimbolikus integráció, közösségalkotás és a konszenzus nélküli egység létrehozása. Az, hogy az egyén erre miképp reagál, csatlakozik vagy kimarad, a demokráciák esetében egyéni döntés kérdése. ${ }^{35}$

A különböző állami megemlékezések esetében fontos megállapítás, hogy az esetek túlnyomó többségében mindig az első emlékezés a fontos, az igazán nagy horderejü. Az ezt követőek már csupán üres ismétlések, melyek a társadalmat sokkal kevésbé mozgatják meg. Ezzel kapcsolatban Aleida Assmann megjegyzi, hogy a politikai emlékezésekkel kapcsolatban nem szabad nagy elvárásokat támasztani, ott „elhangzik, aminek el kell hangzania”, de a múlt feldolgozása nem itt, hanem más színtéren zajlik le. A politikai rítusok csak legritkább esetben válnak igazán karizmatikus rendezvénnyé. Az emlékezés a politikai rendezvényeken és a kulturális szférában egy kódolt formává rögzül, mely könnyen ismételhető. Ez által a forró emlékezés hideggé válik. Ezen megállapítás alapján kijelenthető, hogy a politikai rítus a hideg emlékezés elsődleges színtere. $^{36}$

Ez a fajta hideg emlékezés azonban nem azt jelenti, hogy ezeknek az eseményeknek nem lehet, vagy nincs olyan fontos szerepe. Ezt támasztja alá Patakfalvi-Czirják Ágnes is a Székely Szabadság napjának elemzése kapcsán. Tanulmányában azt írja, hogy a repetitív ünnepségek keretében a székelyföldi autonómiamozgalom kapcsán a múlt felidézése és a jelenhez való kapcsolása lehetővé teszi egy marginalizálódott csoport, valamint annak elitje számára, hogy megszilárdítsa saját legitimitását. Ez a legitimitás a székelyek kapcsán például a Román állammal szembeni pozíció kimondásából és ennek demonstrálásából fakad. Így ez a székely példa a hatalmi elnyomás elleni harc szerepévé válik, és a közösség reprezentációjáért folytatott színtér lesz. ${ }^{37}$ A repetitív ünnepségekkel kapcsolatban fontos kiemelni, hogy ezek az események nem csupán arra alkalmasak, hogy megidézzék a múltat, hanem emlékeztetnek is a múlttal való folytonosságra. Ebben az értelemben ezek nem csupán ismétlések, hanem a múlt egy pontját megragadva megélhetővé is teszik a múltat. A megemlékezés rítusai a teret ezzel

${ }^{34}$ Uo. 108.

35 Uo. 108-109.

36 Assmann 2016: 110-111.

${ }^{37}$ Patakfalvi-Czirják 2018: 221. 
egyfajta szakrális térré alakítják át, a jelenlévőket pedig a rítus szereplőivé avatják, ezzel pedig lényegében olyan közösségi élményt nyújtanak, ami megteremti az elképzelt közösséget, és ezzel az összetartozás élményét. ${ }^{38}$

Ahhoz, hogy megértsük az emlékezetpolitika müködését, érdemes megvizsgálni a nemzeti hős alakjának megteremtését abból a szempontból, hogy milyen mértékben és miképp befolyásolja azt a politika. Az emlékezetpolitika célja, ahogy azt korábban írtam, alapvetően a nemzeti egység megteremtése. A nemzeti múlt egységes értelmezésének megteremtésére az államnak igen színes eszköztár áll rendelkezésére. Ennek érdekét szolgálhatja ugyanis az iskolarendszer, a különböző szimbólumok, dalok, állami ünnepségek, de egészen hétköznapi dolgok is, mint például a nemzeti szimbólumokat ábrázoló és értékesíthető árucikkek. ${ }^{39}$ Guszmann Gergely ezt azzal egészíti ki, hogy a politikai szféra ezeknek a szimbólumoknak a segítségével, lelkesítő és fenyegető beszédekkel, hősök és ellenségek ábrázolásával az emberek érzelmeire kíván hatni. Ezzel a cselekedetével különböző hiedelmeket ébreszt a politika világáról. A politikai valóság efféleképp való misztifikálása a hatalom megőrzését és tartós fenntartását szolgálja. Ezzel azt a látszatot kívánja kelteni, hogy a politika világában csakis ők képesek eligazodni, ennélfogva a társadalomnak égető szüksége van rájuk. ${ }^{40}$

A politikai vezetés az általa megalkotott politikai világot a reprezentáció révén tarja fent, melyet igyekszik a kollektív emlékezet részévé tenni. Erre kiváló lehetőséget nyújt a nemzeti hős, akiben a politikai hatalom által feltüntetni kívánt erények ötvöződnek, és a hatalmat reprezentáló szimbólumként jelenhetnek meg. ${ }^{41}$

Általános tendenciának tekinthető, hogy a nemzet hőseinek, a nemzet nagyjainak reprezentációja emlékhelyekben ölt testet. Ezek széles skálája ismert például szobrok, vagy utcanevek formájában. ${ }^{42}$ Az utcanevek elsősorban funkciójuk kapcsán válnak kiemelten fontos emlékezeti térré, mivel az emlékezést a hétköznapokba viszik bele. Az utcanév sok fórumon szerepelhet: igazolványon, telefonkönyvben, postacímnél stb. Éppen ezért egyediek és erősen politikai célzatúak, mivel sokan megjegyzik őket. $\mathrm{Az}$ utcanevek változásai mindig jelzik a változó politikai akaratot is. Az új rendszer kialakulása gyakran jár az előző rendszer identitásbiztosító terének törlésével, új kialakításával. A totalitárius rendszerek már az elején cserélik az utcaneveket, ezzel erősítve saját bázisuk, és alapozzák meg legitimitásuk. ${ }^{43}$

A sírhelyeknek mindig kiemelt, különleges szerepe van. Gyakran az állam maga jelöl ki területeket, létrehozva olyan temetőket, melyek a nemzet nagyjainak hamvait őrizik. Ezek a helyek ezzel az állam reprezentációjának és legitimációjának is fontos eszközeivé válnak. Ez a pantheonizációs folyamat Nyugat-Európában vált elöször gyakorlattá. A

\footnotetext{
Uo. 222-223.

39 Björnsson 2018: 70.

40 Guszmann 2011: 22-23.

41 Uo. 23.

42 Uo. 29.

43 Alderman 2002: 101.
} 
francia állam a Pantheont jelölte ki ennek színhelyéül, Anglia a Westminster-apátságot. ${ }^{44}$

A pantheonizáció Magyarországon sem ismeretlen fogalom. Hazai viszonylatban a nemzet nagyjainak nyughelyét a Fiumei Úti Sírkertben jelölték ki Budapesten. A temető 1885-ben kapott dísztemetői státuszt. Nem csupán a klasszikus értelemben vett nemzeti hősöket temették ide, hanem a magyar nemzet azon nagy alakjait is, akik valamilyen módon nyomot hagytak a történelemben. Az ide temetettek a magyar nemzetet hivatottak reprezentálni, egyes személyek esetében maga a síremlék, mauzóleum is beszédes, hiszen az adott személy jelentőségét növelheti, személyes nagyságát tudják kifejezni vele. A Fiumei Úti Sírkertben nyugvók zömmel a 19. század kiemelkedő államférfijei, művészei, írói. De találhatunk néhány 20. századi személyt is, akik közül jónéhány megítélése erősen megosztó hatású a magyarság körében. ${ }^{45}$

A nemzet reprezentációjában a nemzeti hős alakjának kulcsszerepe van, mivel ő testesíti meg a nemzeti erényeket. Ezen személyek nemzeti pantheonba való beemelése kévés kivétellel a 19. századra tehető, és a nacionalizmussal hozható összefüggésbe. E személyek olyan stabil pontot jelentenek, akik azonosságtudattal látják el a nemzet egyes tagjait, ezzel együtt pedig a politikai hatalom arcaivá is válhatnak. Guszmann Gergely definíciója alapján a nemzeti hős alakja több kategóriára bontható, mindegyik mást képes megjeleníteni a nemzetből. Így például elkülöníthetünk írókat, filozófusokat. Ilyen önálló kategóriát képez az államférfi alakja is, aki elsősorban arra alkalmas, hogy megteremtse a nemzeti integritást. ${ }^{46}$

A sírhelyek és utcanevek mellett néhány szót kell ejteni a szobrokról is. A szobrok elsődlegesen a politikai legitimáció megteremtését szolgáló alkotások. Ezek az emlékmüvek az azonosulás lehetőségét kínálják fel a szemlélőnek, mely alapján képes lehet kialakítani saját identitását. Azt azonban meg kell említeni, hogy ez nem egyfajta kötöttséget jelent, sokkal inkább egy andersoni elképzelt közösséget. ${ }^{47}$ A szoborállítás mindig tudatos. Ez a fajta célzott emlékezetpolitika a reprezentációra épít, megteremtve ezzel a kívánt nemzettudatot, látásmódot. Tipikus példák erre az 1871-ben létrejött Német Császárság, mely a győzedelmes nép képét kívánta megteremteni, de a 19. századi Nelson és Wellington szobrokat elöszeretettel használó Anglia is, mely az angol imperializmus nagyságának kívánt emléket állítani. ${ }^{48}$

Általában a nemzet nagyjaira való emlékezés fö színtere a nemzeti ünnep, ahol, ahogy azt korábban írtam, a hatalom kifejezheti kontinuitását a múlt nagyjaival. A múltba való visszanyúlás mellett azonban a hősök emlékezetét a jövő generációjának is sugározzák, így a korábbi nagy tetteket nem csupán a jelennel, hanem a jövővel is összekapcsolják. ${ }^{49}$ Ehhez igen hasonló következtetésre jut Patryk Wawrzyński, amikor a kormányok emlékezetpolitikájáról ír. Itt az állami megemlékezésekkel kapcsolatosan

\footnotetext{
44 Guszmann 2011: 29.

45 Tóth 2008.

46 Guszmann 2011: 34-35.

47 Uo. 35-36.

48 Uo. 40-42.

49 Uo. 44., 46.
} 
három tulajdonságot határoz meg. Ez alapján a megemlékezés feladata az emberek viselkedésének és identitásának alakítása, valamint a jövőkép formálása. Célja pedig, hogy a társadalom számára a valóság egyszerüsített értelmezését adja, melyet a polgárok saját belátásuk alapján használhatnak fel..$^{50}$

A nemzeti hősre való emlékezés egy speciális, Magyarországon talán kevésbé jellemző példája, amikor a múlt nagy alakjára különösen élénk emlékezettel tekintenek vissza. Vagyis úgy teremtenek belőle hivatkozási alapot, mintha napjainkban is élő személyről lenne szó. Ez a gyakorlatban Páll Björnsson szerint abban mutatkozik meg, hogy olyan kérdések születnek a sajtóban, mint hogy „Ma kire szavazna?” „Mit mondana a kérdésről?”, és így tovább. Ennek a jelentősége leginkább abban rejlik, hogy arra mutat rá, egyes csoportok miképp értelmezik a múltat és próbálják használhatóvá tenni a jelenben. ${ }^{51}$

Szintén igen ritka, de nem példanélküli, hogy egyes nemzeti hősök olyan mértékben képesek lefedni a nemzetet, hogy még az egymástól eltérő nézeteket valló jobb- vagy baloldal számára is hivatkozási alapot nyújthatnak. Ilyenek például a Björnsson által is tárgyalt Jón Sigurðsson Izlandon, Giuseppe Garibaldni Olaszországban, George Washington és Abraham Lincoln az Egyesült Államokban, Magyarországon Kossuth Lajost és Petőfi Sándort is ide sorolhatjuk. ${ }^{52}$ Az ilyen egységesítő személyek azonban ritka kivételnek számítanak. Sokkal gyakoribb, különösen az egykori politikusok esetében, hogy nem képesek kivívni ezt az egységesítő nemzeti hős státuszt. Páll Björnsson ennek kapcsán két okot feltételez. Az első, hogy az egykor meghatározó politikus politikai öröksége nem válik széles körü tisztelet tárgyává, a másik a hosszú hivatali idő. Itt ugyanis Björnnson azt emeli ki, hogy a minél hosszabb hivatali idő lehetőséget ad a politikusnak arra, hogy népszerütlenné váljon. Itt klasszikus példaként Otto von Bismarck alakja hozható fel. ${ }^{53}$

A hősök tisztelete nem csupán össznemzeti jelenségként fogható fel. Beszélhetünk lokalitásról, lokális dicsőségről is. Ez az olyan hősök tiszteletét jelenti, akik a közösségért cselekedtek jót, ezzel elindítva valamilyen pozitív változást a település életében. Vagyis olyat cselekedtek, ami kiemelésre méltó és a jövő számára megőrzendő. ${ }^{54}$

\footnotetext{
50 Wawrzyński 2017: 296-297.

51 Björnsson 2018: 75.

52 Uo. 75-76

53 Uo. 76.

54 Guszmann 2011: 48.
} 


\section{Public History}

Végezetül szót kell ejtenem a public history jelentőségéről, mint arról a jelenségröl, ami nagymértékben képes befolyásolni a kollektív emlékezetet. A public history az Amerikai Egyesült Államokban alakult ki az 1970-es években. Viszonylag hamar, már az 1980-as években elterjedt szinte az egész világban. Thomas Cauvin értelmezésében a jelentősége abban áll, hogy az akadémiai történetírás eredményeit könnyen értelmezhető módon tárja a széleskörü, történelem iránt érdeklődő hallgatóság elé. ${ }^{55}$ Fischer a public historyt a történelempolitika egyik részterületeként határozza meg. ${ }^{56} \mathrm{~A}$ public history fogalmát Gyáni Gábor úgy definiálja, mint olyan köztörténelemet, ami a múlt prezentálásával szolgál, és amire a társadalomnak égető szüksége van, illetve amire igényt tart. Így valójában szinte kizárólag a kollektív emlékezet formálja, azon belül pedig a Jan Assmann által ismertetett kommunikatív emlékezet. Ugyanis a public history legkönnyebben az élő emlékezet felé képes fordulni. Lényege, hogy számukra könnyebben befogadható legyen. A tudományos történelemmel szembe-helyezve a legfőbb különbség a következő: Még a tudományos történelem mindig kérdéseket vet fel, addig a public history kész válaszokkal áll a közönség elé. ${ }^{57}$

Ami miatt a public history a kutatásom kapcsán nem kerülhető meg az, hogy a tömegkultúra elterjedésével ez lett a múltra való emlékezés egyik legfőbb közege. A történelemmel kapcsolatos tv-csatornák, filmek, történelmi ismeretterjesztő magazinok, nemzeti rockzene, és még sorolhatnám, mind a public history részét képezi. Ezek pedig igen szoros, bár esetenként különböző kapcsolatokban állnak a kollektív emlékezettel. ${ }^{58}$ Az előbb említettek nagy népszerüsége miatt robbanás-szerüen növekedett a történelmet populárisan bemutató különféle munkák száma. Ezek közül talán a legnépszerübbnek a különböző történelmi eseményeket bemutató dokumentumfilmek és sorozatok. Ezek többségében II. világháború-orientáltak. De nagy eladási számokat képesek produkálni az egyes történelmi magazinok is, mint amilyen például a Magyarországon is megjelenő BBC History. Ezek népszerűsége Jill Liddington alapján abban rejlik, hogy az emberek bele tudnak helyezkedni a múltba, mely átélhetővé válik, különösen a televízió révén. Azzal, hogy a múlt csupán egy kattintásra került mindenkitől, a múlt prezentációi körbevesznek minket. A public history, és ezzel együtt a múlt, egy üzleti ágazattá is vált. Liddington szerint azzal, hogy a múlt ilyenformán bárki számára elérhető, lényegében mindenki nyilvános történelem-képviselője lett/lesz, akár akkor, ha az őseit kutatja, de abban az esetben is, ha megnéz egy dokumentumfilmet. ${ }^{59}$

55 Cauvin 2018: 22.

${ }^{56}$ Fischer2012: 392.

57 Gyáni 2012: 361.

${ }_{58}$ Uo. 362-363.

${ }^{59}$ Liddington 2002: 83-84. 
A public history érdeklődése elég sokszínű lehet. Az Egyesült Államokban jól kiépített és intézményi keretek közt müködtetett irányzatról van szó, mely igen változatosan igyekszik a múltat a nagyközönség elé tárni. ${ }^{60}$

Az angol minta ettől némiképp eltér. A szigetországban a központi helyet a public historyban a nemzeti örökség és emlékezet foglalja el. Ez abból fakad, hogy „emlékszünk dolgokra, krónikákat, történeteket olvasunk és hallunk és az elöző korok relikviái közt élünk", vagyis közel érzik magukhoz a múltat. Ez olyan szemléletet feltételez, ahol a kollektív emlékezetet nagyban meghatározza a személyes élmény, tapasztalat. A public history pedig alkalmas arra, hogy a különböző történeteket leírva összekösse a múltat és a jelent, akár a múlt manipulálásának segítségével is. ${ }^{61}$

A public history német modellje gyakorlati szempontból közelíti meg a problémát. Bár a public history kevésbé intézményesült, mint az Egyesült Államokban, az egyetemeknek köszönhetően mégis létrejött a tudományos történelem és a public history egyfajta keveréke. A német program lényege, hogy az egyetemek olyan gyakorlati tudást biztosítsanak a tanulók számára, melyet felhasználva a tudományos kutatások eredményeit is sikeresen tárhatják a szélesebb nyilvánosság elé. Emellett arra is külön figyelmet szentelnek, hogy az ott használt tudást a történelemtanításban is fel lehessen használni, így könnyítve meg a diákok számára az információk befogadását. $^{62}$

Gyáni Gábor meghatározása szerint Magyarországon a public history legkedveltebb témái: Trianon, a II. világháború, a magyar őstörténet és 1956. Véleményem szerint ezek mellett szintén fontos szerepet kapnak a különböző életrajzok is, amelyeket általában a személyhez kapcsolható meghatározott dátumkor pl. születésének évfordulója, mintegy megemlékezésként közölnek. ${ }^{63}$ Ezeket a megállapításokat támasztja alá A múlt arcai című monográfiájában Romsics Ignác is. A könyvben ugyanis azokkal a magyarországi személyekkel és egyénekkel foglalkozik, akik véleménye szerint emlékezésre méltók, vagy nagy horderejü vitákat képesek kiváltani, ezzel alkalmasak a múlt jelenben való felhasználására is. A már Gyáni Gábornál is említett magyar őstörténet és Trianon Romsicsnál is felmerül. A munkájában azonban ő csak a Horthy-korszakig tekint vissza. Így a munkában megjelenik, mint említésre méltó esemény, a kiegyezés és a mohácsi csatavesztés is. A magyar történelem emlékezésre méltó személyeit tekintve Szent Istvánt, Horthy Miklóst, Bethlen Gábort, Dózsa Györgyöt és Martinovics Ignácot emeli ki. ${ }^{64}$ Utóbbi kettőnél azonban említést tesz egy-egy problémáról. Dózsa György esetében megjegyzi, hogy a személye inkább az államszocializmus korában volt az érdeklődés tárgya, a rendszerváltás után alakja a feledés homályába süllyedt. ${ }^{65}$ Martinovics Ignác személye pedig annyira megosztóvá és egyben vállalhatatlanná vált,

\footnotetext{
60 Uo. 85.

61 Uo. 87.

62 Nießer-Tomann 2018: 15.

63 Gyáni 2012: 362-363.

64 Romsics 2015.

65 Uo. 158.
} 
hogy napjainkban szinte teljesen alkalmatlan arra, hogy a használható múlt fogalma alapján politikai legitimációs erőként alkalmazható legyen. ${ }^{66}$

A public history hazai jelentőségét továbbá az is növeli, hogy a magyarokban megtalálható egyfajta kultikus jellegü befogadás. Gyáni ezt úgy magyarázza, hogy minden múltról szóló hír vagy olvasmány a feltétlen igazság erejével képes hatni. Egyszerübben megfogalmazva: a magyarok jelentős részéből hiányzik a kritikai attitűd, mely az információk szelektálása miatt lenne fontos. ${ }^{67}$

Gyáni Gábor végső konklúziója a public history kapcsán az, hogy a történész nem engedhet meg akkora szabadosságot, mint a nyilvános történelem képviselője. Vitázni sem érdemes vele, mivel az színvonalában igen lehangoló lehet. Ugyanakkor a történész nem hagyhatja figyelmen kívül őket, mivel a kollektív emlékezettel való szoros kapcsolat miatt a public history jól rá tud mutatni a nemzet érdeklődésének főbb irányaira. ${ }^{68}$

\section{Összegzés}

Végezetül ki kell emelni azt, hogy az emlékezetet nagyban befolyásoló tényezőknek, mint a kollektív emlékezet, az emlékezetpolitika és a public history, elsősorban az a szerepe, hogy a jelen számára a múltat átélhetővé tegye. Vagyis összekösse a jelent és a múltat, melyek mellett képes a jövőbe tekinteni és példát állítani a jövő generációja felé, megalapozva ezzel annak szocializációját. Fontos továbbá a legitimáló funkció említése, mely általában a mindenkori hatalom támasztékául képes szolgálni. A legitimáló funkcióval szorosan összefüggésbe hozható a reprezentációs funkció is, hiszen egyes csoportok, vagy akár maga a nemzet is, ez által képes kifejezni, megjeleníteni önmagát, vagy azt a képet önmagáról, melyet a külvilágnak, vagy a társadalom különböző csoportjainak mutatni kíván. Ezen tényezők vizsgálata és értelmezése nagyban megkönnyítheti a különböző emlékezeti vizsgálódásokat, és hozzájárulhat ahhoz, hogy ne csak leírjuk, hanem értsük is a folyamatok müködését.

66 Uo. 292.

67 Gyáni 2012: 358-360.

68 Uo. 365. 


\section{Hivatkozott szakirodalom}

Alderman, Derek H. 2002: Street names and the scaling of memory: The politics of commemorating Martin Luther King, Jr within the African American community. Historical Geography 30. 99-102.

Anderson, Benedict 1996: Imagined communities. Reflections ont he Origin and Spread of Nationalism. New York.

Assmann, Aleida 2016: Rossz közérzet az emlékezetkultúrában. Beavatkozás. Budapest.

Assmann, Jan 2018: A kulturális emlékezet. Írás, emlékezés és politikai identitás a korai magaskultúrákban. Budapest.

Björnsson, Páll 2018: Egy nemzeti hős megalkotása. Jón Sigurðsson (1811-1879) emlékezete és a nemzeti egység megteremtése Izlandon. Aetas 33. 69-78.

Burke, Peter 2001: A történelem, mint társadalmi emlékezet. Regio 12. 3-21.

Cauvin, Thomas 2018: The rise of public history: An international perspective. Historia Crítica 68. 3-26.

https://doi.org/10.7440/histcrit68.2018.01

Fischer, Holger 2012: Public history, emlékezetkultúra, történelempolitika. Helyük Németország jelenkori történettudományában. Történelmi Szemle 54. 389-410.

Guszmann Gergely 2011: A nemzeti hős alakjának megkonstruálása a független Indiában. A Bharatiya Janata Párt nemzetépítő törekvései 1998-2004. Doktori disszertáció. Budapest.

Gyáni Gábor 2012: Nemzet, kollektív emlékezet és public history. Történelmi Szemle 54. $357-375$.

Gyáni Gábor 2016: A történelem mint emlék(mü). Budapest.

Gyáni Gábor 2017: A felejtés mint politikai mítosz. Korall 67.22-34.

Hobsbawn, Erik 1983: Introduction: Inventing tradition. In: Hobsbawm, Erik - Ranger, Terence (szerk.): The invention of tradition. Cambridge. 1-14.

https://doi.org/10.1017/CBO9781107295636.001

Keszei András 2010: Az emlékezet rétegei. Korall 41. 5-34.

Liddington, Jill 2002: What is public history? Publics and their pasts, meanings and practices. Oral History 30. 83-93.

Nießer, Jacqueline - Tomann, Juliane 2018: Public and Applied History in Germany: Just another Brick in the Wall of the Academic Ivory Tower? The Public Historian 40. 11-27.

https://doi.org/10.1525/tph.2018.40.4.11 
Nora, Pierre 2010: Emlékezet és történelem között - Válogatott tanulmányok. Budapest.

Patakfalvi-Czirják Ágnes 2018: Ünnepélyes keretek között újra és újra kimondani. A Székely Szabadság Napjának elemzése. In: Filep Tamás Gusztáv (szerk.): Ünnep és felejtés. Emlékezet, identitás, politika. Budapest. 216-250.

Romsics Ignác 2015: A múlt arcai. Történelem, emlékezet, politika. Budapest.

Tóth Vilmos 2008: A Fiumei Úti Sírkert. Budapest.

Wawrzyński, Patryk 2017: The Government's Remembrance Policy: Five Theoretical Hypotheses. Polish Political Science Yearbook, 46. 294-312.

https://doi.org/10.15804/ppsy2017119 